\title{
Analisis kondisi sosial ekonomi pekerja sektor informal (studi kasus pedagang laki lima yang berada dilingkungan jembatan Gentala Arasy Kota Jambi)
}

\author{
*Fitri Maulida; Zamzami; Jaya Kusuma Edy \\ Prodi Ekonomi Pembangunan, Fak. Ekonomi dan Bisnis, Universitas Jambi \\ *E-mail korespondensi: fitrimaulida01@gmail.com
}

\begin{abstract}
The purpose of this study was to analyze the social economic conditions of street vendors around the Gentala Arasy bridge. The sample of this research was 44 respondents's experiments. The variables in this study are age, education level, working hours, and capital. Data collection techniques using questionnaires, documentation, and interviews. Data analysis used is the coefficient of determination test and hypothesis test simultaneously. The results obtained from this study include socioeconomic street vendors age, education level, and capital proven to increase, only the working hours variable is not increased. The results of the analysis of the coefficient of determination in this study are all statement items have a valid or significant status because the value of $t$ count $>t$ table with the value of $R^{2}$ Square (0.348) and the results of the hypothesis test show items that correspond to high reliability with a value $(0.270$ a $<0.05)$
\end{abstract}

Keywords: Analysis of socio-economic conditions, income, age, education level, working hours, capita.

\begin{abstract}
Abstrak
Tujuan dari penelitian ini untuk menganalisis Kondisi Sosial Ekonomi Pedagang Kaki Lima di sekitar Jembatan Gentala Arasy. Sampel penelitian ini berjumlah 44 responden. Variabel dalam penelitian ini adalah Umur, Tingkat Pendidikan, Jam Kerja, dan Modal. Teknik pengumpulan data menggunakan angket (kuesioner), dokumentasi dan wawancara. Analisis data yang digunakan yakni Uji Koefisien Determinasi dan Uji Hipotesis secara simultan. Hasil yang diperoleh dari penelitian ini yaitu kondisi sosial ekonomi pedagang kaki lima meliputi Umur, Tingkat Pendidikan dan Modal terbukti meningkat, hanya variabel Jam Kerja saja yang tidak begitu meningkat. Hasil analisis uji koefisien determinasi dalam penelitian ini adalah semua item peryataan memiliki status valid atau signifikan karena nilai t hitung > t tabel dengan nilai $\mathrm{R}^{2}$ Square $(0.348)$ dan hasil uji hipotesis menunjukkan bahwa item pernyataan termasuk dalam reabilitas tinggi dengan nilai sig anova $\left(0.270^{\mathrm{a}}<0.05\right)$.
\end{abstract}

Kata Kunci: Analisis kondisi sosial ekonomi, pendapatan, umur, tingkat Pendidikan, jam kerja, modal.

\section{PENDAHULUAN}

Bekerja merupakan salah satu cara untuk mempertahankan hidup. Pada hakekatnya dalam mempertahankan hidupnya manusia mempunyai kebutuhan hidup 
yang tidak terbatas dan bermacam-macam ragamnya. Dalam kehidupan sehari-hari manusia memiliki banyak jenis kebutuhan demi mempertahankan hidupnya. Kebutuhan tersebut dapat dibagi menjadi dua kategori yakni : a). Kebutuhan primer adalah kebutuhan yang paling utama untuk mempertahankan hidup seperti: makan, minum, pakaian, perumahan, kesehatan, dan pendidikan. b). Kebutuhan Sekunder adalah kebutuhan yang dipergunakan untuk melengkapi kebutuhan primer seperti: alat-alat dan perabot.

Kota Jambi adalah salah satu kota besar yang ada di provinsi Jambi. Kotajambi memberikan berbagai peluang dan kesempatan untuk mengadu nasib mencari kebutuhan penghidupan. Kehidupan yang kompleks dengan bertambahnya 2 penduduk dari desa ke kota (urban) di suatu kota membuat pemerintah setempat memperhatikan adanya keberadaan mereka salah satunya adalah pedagang yang biasanya di temui di pinggir-pinggir jalan.

Perkembangan perekonomian suatu negara maupun daerah tidak terlepas dari aktivitas perekonomian masyarakat.Perekonomian tersebut terbentuk dari beberapa sektor usaha baik sektor formal maupun sektor informal dengan tujuan untuk mendapatkan penghasilan yang layak dalam memenuhi kebutuhan hidup serta untuk menyejahterakan anggota keluarganya.Sektor Informal merupakan unit usaha kecil yang melakukan kegiatan produksi atau distribusi barang dan jasa untuk menciptakan lapangan pekerjaan dan penghasilan bagi mereka yang terlibat unit tersebut dengan keterbatasan baik dari modal,fisik,maupun keahlian salah satu yangtermasuk sektor informal yaitu pedagang kaki lima (PKL). Untuk itu usaha sektor informal dalam perkembangannya yang semakin luas dan nyata perlu dibina dan dilindungi agar tumbuh menjadi unsur kekuatan ekonomi. Dalam usaha perkembangan usaha sektor informal sangat diperlukan peranan pemerintah. Dalam hal ini pemerintah harus selalu berupaya untuk mendorong dan menciptakan iklim usaha yang kondusif agar usaha kecil tersebut dapat terus tumbuh dan berkembang dengan baik. Dengan demikian, usaha kecil akan menjadi kekuatan ekonomi yang tangguh dan mandiri serta dapat memperkuat struktur perekonomian nasional sehingga usaha kecil benar-benar menjadi tulang punggung perekonomian nasional. (Prawirokusumo, 2001).

Kemampuan sektor informal dalam menampung tenaga kerja didukung oleh faktor-faktor yang ada. Faktor utama adalah sifat dari sektor ini yang tidak memerlukan persyaratan dan tingkat keterampilan, sektor modal kerja, pendidikan ataupun saranayang dipergunakan semuanya serba sederhana dan mudah dijangkau oleh semua anggota masyarakat atau mereka yang belum memiliki pekerjaan dapat terlibat didalamnya. Salah satu sektor yang kini menjadi perhatian para pencari lapangan pekerjaan adalah sektor tenaga kerja yang sifatnya informal. Sektor informal ini beroperasi pada tempat-tempat tertentu terutama di setiap pusat keramaian.

Breman dalam Darman (2015) menyatakan bahwa sektor informal meliputi masa pekerja kaum miskin yang tingkat produktifitasnya jauh lebih rendah dari pada pekerja di sektor modern di kota yang tertutup bagi kaum miskin..

Dalam usaha berdagang ada beberapa faktor yang dapat mempengaruhi tingkat pendapatan yang diterima oleh para pedagang tersebut seperti modal, umur, tingkat pendidikan dan jam kerja.Fitria (2014) menemukan bahwa modal, tingkat pendidikan, jam kerja serta lama usaha berpengaruh signifikan terhadap pendapatan pedagang.

Sutrisno dalam Nurhayati (2017) menyatakan bahwa modal operasional adalah dana yang diperlukan oleh perusahaan untuk memenuhi kebutuhan operasional perusahaan sehari-hari, seperti pembelian bahan baku, pembayaran upah buruh, membayar hutang dan pembayaran lainnya. Modal awal merupakan faktor penting 
dalam kegiatan usaha. Semakin besar modal awal, maka semakin luas kesempatan untuk mengembangkan usaha. Modal awal terdiri dari modal sendiri dan modal bukan milik sendiri yang biasanya berupa pinjaman. Beberapa penelitian terdahulu terhadap sektor informal menyatakan bahwa terdapat keterkaitan langsung antara modal awal dengan tingkat pendapatan.

Umur sangat berpengaruh terhadap pendapatan karena semakin tua umur istri, maka produktifitasnya semakin menurun dan kondisi fisiknya semakin lemah sehingga tidak mampu menyumbangkan pendapatan dalam keluarga (Sudarmini, 2006).

Menurut Marchaeni dan Manuati (2004), orang yang berpendidikan lebih tinggi mulai dengan pendapatan yang lebih rendah, tapi dengan cepat menyalip mereka yang memiliki pendidikan yang lebih rendah. Artinya, pedagang perempuan yang mempunyai pendidikan lebih tinggi akan mampu meningkatkan pendapatannya.

Dalam hal lamanya jam kerja, biasanya pedagang yang mempunyai jumlah jam kerja lebih lama, maka pendapatannya akan lebih maksimum. Sugeng (2009), menyimpulkan bahwa jam kerja berpengaruh terhadap pendapatan perempuan dalam perekonomian rumah tangga. Semakin lama jam kerja perempuan, maka semakin banyak hasil yang diterima sehingga kebutuhan keluarga bisa terpenuhi.

Kemampuan sektor informal dalam menampung tenaga kerja didukung oleh faktor-faktor yang ada. Faktor utama adalah sifat dari sektor ini yang tidak memerlukan persyaratan dan tingkat keterampilan, sektor modal kerja, pendidikan ataupun sarana yang dipergunakan semuanya serba sederhana dan mudah dijangkau oleh semua anggota masyarakat atau mereka yang belum memiliki pekerjaan dapat terlibat didalamnya, salah satu sektor yang menjadi perhatian para pencari lapangan pekerjaan adalah sektor tenaga kerja yang sifatnya informal. Sektor informal ini beroperasi pada tempat-tempat tertentu terutama disetiap pusat keramaian.

Jumlah persentase penduduk di Kota Jambi berumur 15 tahun keatas yang bekerja menurut status pekerjaan pada tahun 2014, 2015 dan 2016 (BPS). Tahun 2014,sektor informal di Kota Jambi mendominasi pekerja menurut status pekerjaan dengan persentase sebesar 36,99\% dan sisanya bekerja di sektor formal sebesar 5,33\%. Tahun 2015, sektor informal di Kota Jambi juga masih mendominasi sebesar 35,60\% dan sisanya bekerja di sektor formal sebesar 7,85\% . Tahun 2016, sektor informal di Kota Jambi menurun drastis pekerja menurut status pekerjaan dengan persentase sebesar $16.99 \%$ dan sisanya bekerja di sektor formal sebesar $4,31 \%$.

Kota Jambi tak lepas dari sektor informal, hal ini dikarenakan di Kota Jambi menjadi salah satu pusat keramaian yang ada di Jambi karena terdapat tempat pariwisata Gentala Arasy. Berbagai lapangan pekerjaan dalam sektor informal hadir di tempat pariwisata Gentala Arasy dengan menawarkan berbagai macam profesi pedagang keliling, pedagang kaki lima, maupun pedagang di warung. Pedagang kaki lima umumnya bisa ditemui hampir di setiap jalan di depan pagar jembatan Gentala Arasy dan usaha yang di perdagangkan nya seperti pedagang makan dan minuman, pedagang buah-buahan, pedagang rokok dan obat-obatan, pedagang kacamata, dan pedagang gelang dan laim-lain. Saat ini masyarakat sekitar Gentala Arasy menjadi pedagang kaki lima, khususnya yang berjualan pada malam hari di lingkungan jembatan Gentala Arasy.Berdasarkan uraian, penulis tertarik untuk mengamati kondisi sosial ekonomi sektor informal yaitu pedagang kaki lima di lingkungan jembatan gentala Arasy. 


\section{METODE}

\section{Pendekatan penelitian}

Adapun jenis penelitian yang digunakan dalam penelitian ini adalah metode survei. Metode survei adalah penelitian yang mengambil sampel dari populasi dengan menggunakan kusioner sebagai alat pengumpul data dimana peneliti langsung ke lokasi penelitian untuk mengumpulkan data serta fakta dari gejala-gejala yang ada untuk mencari keterangan keterangan secara faktual (Singarimbun, 2002).

\section{Jenis dan dumber data}

Sesuai dengan metode yang digunakan dalam penelitian ini adalah metode survei, maka pengumpulan data dan informasi yang di perlukan dilakukan sebagai berikut :

Menurut Hasan (2002) data primer ialah data yang diperoleh atau dikumpulkan langsung di lapangan oleh orang yang melakukan penelitian atau yang bersangkutan yang memerlukannya. Data primer di dapat dari sumber informan yaitu individu atau perseorangan seperti hasil wawancara yang dilakukan oleh peneliti. Responden yang dimaksud adalah pedagang kaki lima pada lingkungan Jembatan Gentala Arasy.

Data sekunder adalah data yang diperoleh atau dikumpulkan oleh orang yang melakukan penelitian dari sumber-sumber yang telah ada (Hasan, 2002). Data ini digunakan untuk mendukung informasi primer yang telah diperoleh yaitu dari bahan pustaka, literatur, penelitian terdahulu dan buku.

\section{Populasi dan sampel}

Syaifuddin (2013), populasi merupakan sebagai keseluruhan atau totalitas dari semua unsur-unsur dari suatu objek yang diamati dan diteliti. Sementara itu populasi juga merupakan sebagai totalitas dari semua objek atau individu tertentu, jelas dan lengkap yang akan diteliti. Populasi yang dimaksud dalam penelitian ini adalah PKL (pedagang kaki lima) yang berada di lingkungan Gentala Arasy berjumlah 105 pedagang.

Sampel adalah bagian dari jumlah dan karateristik yang dimiliki oleh populasi tersebut. Metode sampling yang digunakan adalah purposive sampling, yaitu teknik penentuan sampel berdasarkan pertimbangan tertentu. Sampel yang akan diteliti adalah para wisatawan yang berkunjung ke Gentala Arasy. Pengambilan sampel dalam penelitian ini menggunakan rumus slovin dengan tingkat kesalahan $15 \%$, dirumuskan sebagai berikut :

Keterangan:

$$
n=\frac{\mathbf{N}}{1+N(e)^{2}}
$$

$n$ : Jumlah sampel

$N$ : Jumlah populasi

e : Tingkat kesalahan/standar error

$$
\begin{gathered}
n=\frac{105}{1+105(15 \%)^{2}} \\
n=\frac{105}{1+105(0,0225)} \\
n=\frac{105}{2,385}=44,02(44)
\end{gathered}
$$




\title{
Teknik pengumpulan data
}

Pengumpulan data dilakukan dengan mengadakan tanya jawab langsung kepada obyek yang diteliti atau menggunakan kuesioner dari responden yang lebih mendalam

\begin{abstract}
Alat analisis data
Definisi metode analisis deskriptif menurut Sugiyono (2013) adalah penelitian yang dilakukan untuk mengetahui nilai variabel mandiri, baik satu variabel atau lebih (independen) tanpa membuat perbandingan, atau menghubungkan dengan variabel yang lain.Metode analisis deskriptif ini menggunakan kuisioner kepada responden dengan tujuan untuk mengetahui data karakteristik sosial dan ekonomi PKL makanan yaitu umur, jenis kelamin, status perkawinan, jam kerja, tingkat pendidikan, pendapatan dan modalMetode analisis data yang digunakan dalam penelitian ini adalah metode analisis deskriptif dan kuantitatif. Untuk menjawab tujuan pertama dalam penelitian ini berkaitan dengan karakteristik sosial ekonomi pedagang kaki lima di lingkungan Jembatan Gentala Arasy, maka digunakan analisis deskriptif dengan menggunakan tabel tabulasi sehingga dapat menggambarkan karakteristik sosial ekonomi yang antara lain: jenis kelamin, umur, tingkat pendidikan, jumlah tanggungan keluarga, status pekerjaan, lamanya usaha, jumlah jam kerja, dan tingkat pendapatan.

Untuk menjawab tujuan kedua penelitian yaitu pengujian hipotesis yang telah dikemukakan mengenai pengaruh usia, lama usaha, modal, dan lamanya jam kerja terhadap pendapatan yang di peroleh oleh pedagang kakilima di lingkungan Jembatan Gentala Arasy mengunakan analisis berganda. Menurut Wohon.dkk,(2017) regresi linear terbagi menjadi dua yaitu regresi linear sederhana dan regresi linear berganda. Regresi linear sederhana merupakan model regresi linear yang terdiri dari satu variabel terikat $(\mathrm{Y})$ dan satu variabel bebas $(\mathrm{X})$, sedangkan regresi linear berganda merupakan model regresu yang terdiri dari beberapa variabel bebas atau lebih dari dua dan memiliki satu variabek terikat.
\end{abstract}

$$
\mathbf{P}=\boldsymbol{\beta 0}+\boldsymbol{\beta}_{1} \mathrm{U}+\boldsymbol{\beta}_{\mathbf{2}} \mathbf{P d}+\boldsymbol{\beta}_{3} \mathbf{J K}+\boldsymbol{\beta}_{\mathbf{4}} \mathbf{M}+\boldsymbol{\mu}
$$

Keterangan :

$\mathrm{P} \quad$ : Pendapatan responden (Rp perbulan )

$\mathrm{U}:$ Umur reponden (tahun)

$\mathrm{Pd}$ : Tingkat pendidikan responden (tahun)

JK : Lamanya jam kerja responden (jam perbulan)

M : Model operrasional responden ( $\mathrm{Rp}$ perbulan)

$\beta 0$ : Konstanta

$\beta_{1}, \beta_{2}, \beta_{3}, \beta_{4}$ : Koefisien regresi

$\mu \quad:$ Residu

\section{Uji asumsi klasik}

Winarno (2011) mengartikan multikolinieritas adalah kondisi adanya hubungan linier antarvariabel independen. Karena melibatkan beberapa variabel independen, maka Multikolinieritas tidak akan terjadi pada persamaan regresi sederhana. Ditambahkan lagi oleh Winarno, indikasi terjadinya multikolinieritas ditunjukkan dengan informasi sebagai berikut; 1) Nilai $\mathrm{R}^{2}$ tinggi tetapi variabel independen banyak yang tidak signifikan. 2) Menghitung nilai koefisien korelasi antarvariabel independen. Apabila koefisiennya rendah, maka terdapat multikolinieritas.

Metode yang digunakan untuk mendeteksi ada tidaknya heteroskedasitas adalah dengan menggunakan uji white. Kriteria pengambilan keputusan dalam uji white, 
sebagai berikut: Nilai probabilitas X2 hitung<niai probabilitas kritis $\alpha(0,05)$, maka hipotesis yang menyatakan bahwa tidak ada heteroskedastisitas ditolak. Nilai probabilitas X2 hitung<nilai probabilitaskritis $\alpha(0,05)$, maka hipotesis yang menyatakan bahwa tidak heteroskedastisitas diterima.Apabila dalam suatu model asumsi residual $\left(e_{i}\right)$ memiliki nilai rata-rata nol tidak terpenuhi, yang terpengaruh hanya slope estimator dan tidak membawa konsekuensi serius dalam model. Sedangkan jika asumsi residual memiliki varian yang konstan $\operatorname{var}\left(\mathrm{e}_{\mathrm{i}}\right)=\sigma^{2}$ dan residual suatu observasi tidak saling berhubungan dengan residual observasi lainnya $\operatorname{cov}\left(\mathrm{e}_{\mathrm{i}}, \mathrm{e}_{\mathrm{j}}\right)=0$ dilanggar, maka akan berdampak serius bagi prediksi dengan model yang dibangun (Winarno, 2011).

Banyak metode yang bisa digunakan untuk mendeteksi masalah autokorelasi. Salah satunya adalah metode Breush-godfrey, umun dikenal dengan uji Lagrange Multiplier (LM). Jika chi-square (x) hitung lebih besar dari nilai kritis chi-square pada drajat kepercayaan tertentu $(\alpha)$, maka menolak hipotesis nol $\left(\mathrm{H}_{0}\right)$. Ini menunjukan adanya masalah autokorelasi dalam model. Sebaliknya jika nilai chi-square hitung lebih kecil dari nilai kritisnya maka menerima hipotesis nol. Artinya model tidak mengandung unsur autokorelasi karena semua nilai $\rho$ sma dengan nol. Ada tidaknya autokorelasi juga dapat dilihat dari nilai probabilitas chi-square (x). Jika nilai probabilitas lebih besar dari niali $\alpha$ yang dipilih maka kita menerima $\mathrm{H}_{0}$ yang berati ada maslah autokorelasi.

\section{Pengujian hipotesis}

\section{Koefisien determinasi}

Koefisien derteminasi $\left(\mathrm{R}^{2}\right)$ digunakan untuk mengetahui keeratan antara variabel $\mathrm{X}_{1}, \mathrm{X}_{2}, \mathrm{X}_{3}, \mathrm{X}_{4}$ dengan variabel $\mathrm{Y}$. Perhitungan koefisien determinasi tersebut menggunakan formulasi sebagai berikut $: R 2=1-\frac{\mathrm{E} i}{\mathrm{Y} i 2} \mathrm{Nilai} \mathrm{R}^{2}$ ini anatara $0-1\left(0<\mathrm{R}^{2}<\right.$ 1), semakin mendekati 1 maka nilai $R$ tersebut semakin baik, berarti terdapat hubungan yang kuat anatara variabel dependent dengan variabel independent.

\section{Uji hipotesis secara simultan (Uji F)}

Uji $\mathrm{F}$ digunakan untuk mengetahui signifikan atau tidaknya pengaruh variabel $\mathrm{X}_{1}$ (umur pedagang), $\mathrm{X}_{2}$ (tingkat pendidikan), $\mathrm{X}_{3}$ (jam kerja), dan $\mathrm{X}_{4}$ (modal). Secara bersama- sama (simultan) terhadap variabel $\mathrm{Y}$ (pendapatan pedagang ). Nilai $\mathrm{f}$ hitung di peroleh mengunakan formasi :

Dimana :

$$
F h=\frac{\mathbf{R} 2 /(\mathbf{R}-\mathbf{1})}{(\mathbf{1}-\mathbf{R} 2) /(\mathbf{n}-\mathbf{k})}
$$

Fh : F hitung

$\mathrm{R}$ : Koefisisen determinasi

$\mathrm{K}$ : Jumalah variabel independent (bebas)

$\mathrm{n}$ : Jumlah sampel

Nilai $\mathrm{F}$ hitungn yang didapat selanjutnya dibadingkan dengan nilai $\mathrm{F}$ tabel pada derajat kekebasan (df) dan tingkat tertentu dengan keputusan sebagai berikut :

F hitung $>$ dari $\mathrm{F}$ tabel $\rightarrow \mathrm{H}_{0}$ ditolak

F hitung $<$ dari $\mathrm{F}$ tabel $\rightarrow \mathrm{H}_{0}$ diterima

Apabila nilai $\mathrm{F}$ hitung lebih besar dari nilai $\mathrm{F}$ tabel, maka $\mathrm{H}_{0}$ ditolak yang berarti ada pengaruh (signifikan) anatra variabel dengan variabel independent. Begitu juga sebaliknya apabila $\mathrm{F}$ hitung lebih kecil dari $\mathrm{f}$ tabel, maka $\mathrm{H}_{0}$ diterima yang berarti tidak ada pengaruh (tidak signifikan) anatara variabel independent. 


\section{Uji hipotesis secara persial (Uji t)}

Uji t dimaksudkan untuk mengetahui seberapa besar pengaruh tingkat signifikan variabel independent terhadap variabel dependent secara persial dengan menggunakan formulasi :

Dimana :

$$
T=\frac{\mathbf{b} 2}{\operatorname{Se}(\mathbf{b} 2)}
$$

b : Koefisien regresi hasil estimasi

Se : Simpangan baku atau standar error

Jika t-hitung lebih besar dari nilai t-tabel, maka hubungan antara variabel dependent dan variabel independent adalah signifikan. Apabila t-hitung yang di peroleh lebih besar atau sama dengan t-tabel maka hipotesa nol ditolak. Sebaliknya bila t-hitung lebih kecil dari t-tabel berati hipotesa nol diterima, ini berarti tidak terdapat pengaruh yang signifikan anatra variabel independent terhadap pada tingkat keyakinan tertentu.

\section{HASIL DAN PEMBAHASAN}

\section{Kareteristiksosial ekonomi pedagang kaki lima yang berjualan di jembatan Gentala Arasy}

Karateristik Sosial Ekonomi responden digunakan untuk mengambarkan keadaan atau kondisiresponden yang dapat memberikan informasi tambahan untuk memahami hasil penelitian. Penyajian data deskriptif dalam penelitian ini bertujuan agar dapat dilihat profil dari data keadaan Sosial Ekonomi Pedagang kaki limayang digunakan dalam penelitian.

\section{Karateristik menurut kelompok umur}

Umur merupakan hal yang penting bagi kehidupan manusia, karena sebagai batasan kemampuan untuk melakukan kegiatan dalam kehidupannya dan tinggi rendahnya umur menentukan kapan seseorang dapat bekerja. Sebelum mengetahui karateristik responden berdasarkan umur, terlebih dahulu dilakukan perhitungan skala interval umur dengan umur responden termuda 17 tahun dan umur responden paling tua berumur 56 tahun. Range dari umur 17 tahun ke 56 tahu nadalah 40 tahun. Jika di penelitian ini mengunakan 4 kali interval, maka jarak setiap interval 40:4 =10 artinya jarak interval kategori umur responden 10 tahun.

Dengan mengunakan rumus statistik untuk menentukan data kelompok umur,berikut adalah data kelompok umur pedagang Kaki Lima yang menjadi responden

Tabel 1. Jumlah dan persentase pedagang kaki lima berdasarkan kelompok umur

\begin{tabular}{cccc}
\hline No. & $\begin{array}{c}\text { Umur rata-rata } \\
\text { (tahun) }\end{array}$ & $\begin{array}{c}\text { Jumlah } \\
\text { (Orang) }\end{array}$ & Persentse \\
\hline 1. & $17-27$ & 7 & 15.9 \\
2. & $28-37$ & 14 & 31.8 \\
3. & $38-47$ & 13 & 29.5 \\
4. & $48-56$ & 10 & 22.7 \\
\hline & Jumlah & $\mathbf{4 4}$ & $\mathbf{1 0 0}$ \\
& Rata-Rata Umur & & $\mathbf{2 5}$ \\
\hline
\end{tabular}

Sumber : Data diolah, 2019

Tabel 1 memperlihatkan bahwa responden yang terbanyak terletak 28-37 tahun dengan persentase sabanyak 31.8 persen, dikarenakan kelompok usia 28-37 tahun secara 
umum merupakan kelompok usia yang mana batas kerjanya tidak terikat dengan suatu perusahaan atau sistem kontrak sehinga mereka memlih bekerja sebagai pedagang kaki lima. Sedangkan untuk yang terkecil terletak pada kelompok usia 17-27 tahun dengan persentase sebanyak 15.9 persen. Kelompok usia 17-27 faktor usia yang produktifitas dimana di usia tersebut sangat banyak di butuhkan kariawan dengan usia tersebut sehinga faktor tersebut minim untuk pekerja sebagai pedagang kaki lima. Rata-rata kelompok umur pedagang kaki lima yang menjadi responden adalah 25 dan dibulatkan menjadi 25tahun. Secara rata-rata, umur pedagang kaki lima yang berada di sekitar Jembatan Gentala Arasy berada pada kelompok usia produktif.

\section{Karakteristik menurut kelompok jenis kelamin}

Pengelompokanpedagang kaki lima yang menjadi responden menurut jenis kelamin adalah sebagai berikut :

Tabel 2. menunjukan bahwa dominan pedagang kaki lima yang menjadi responden adalah aki-laki dengan persentase sebesar 63.6 persen sedangkan perempuan dengan persentase sebesar 36.4 persen.

Tabel 2. Jumlah dan persentase pedagang kaki lima berdasarkan kelompok jenis kelamin

\begin{tabular}{lcc}
\hline Jenis Kelamin & Jumlah (Orang) & Persentase \\
\hline Laki-Laki & 28 & 63.6 \\
Perempuan & 16 & 36.4 \\
\hline Jumlah & $\mathbf{4 4}$ & $\mathbf{1 0 0}$ \\
\hline
\end{tabular}

Sumber: Data diolah, 2019

\section{Karakteristik menurut kelompok jumlah tanggungan}

Jumlah tanggungan keluarga adalah jumlah anggota dalam suatu keluarga dan sekaligus menjadi beban tanggungan kepala. Dalam hal ini termasuk didalamnya anak dan orang tua yang tinggal di daerah lain,akan tetapi tetap di biayai oleh kepala keluarga, sanak family maupun orang lain yang tinggal serumah tetapi menjadi tanggungan. Dengan menggunakan rumus statistik untuk menentukan data kelompok jumlah tanggungan keluarga, berikut adalah data kelompok jumlah tanggungan keluarga, berikut adalah data kelompok jumlah tanggungan pedagang kaki lima yang menjadi responden

Tabel 3. Jumlah dan persentase pedagang kaki lima

\begin{tabular}{cccc}
\hline No. & $\begin{array}{c}\text { Jumlah Tangungan } \\
\text { (Orang) }\end{array}$ & Jumlah (Orang) & Persentase (\%) \\
\hline 1 & 0 & 8 & 18.2 \\
2 & 1 & 6 & 13.6 \\
3 & 2 & 7 & 15.9 \\
4 & 3 & 13 & 29.5 \\
5 & 4 & 6 & 13.6 \\
6 & 5 & 3 & 6.8 \\
7 & 6 & 1 & 2.3 \\
\hline Jumlah & & $\mathbf{4 4}$ & $\mathbf{1 0 0}$ \\
Rata-Rata & & $\mathbf{1 5}$ orang & \\
\hline
\end{tabular}

Sumber : Data diolah, 2019

Tabel 3. menunjukan bahwa jumlah tanggungan responden terbesar ada pada jumlah tanggungan 3 orang yaitu 29.5 persen. Lalu di ikuti dengan jumlah tanggungan 1 
sampai 4 orang yaitu dengan persentase sebesar 18.2 persen, dan diikuti lagi jumlah tanggungan 5 orang sebesar 6.8 persen. Sedangkan jumlah tanggungan 6 orang menjadi yang terkecil dengan persentase sebesar 2.3 persen. Untuk rata-rata (mean) dari responden menurut jumlah tanggungan adalah 15 orang.

\section{Karakteristik menurut kelompok tingkat pendidikan}

Yang di maksud dengan tingkat pendidikan adalah tingkat pendidikan formal yang pernah di tempuh oleh responden. Pembagian dalam tabel 5.5 sesuai dengan urutan tingkat pendidikan dengan tahun sukses yang berhasil ditempuh responden, dimulai dari sekolah dasar (SD), sekolah menengah atas (SMA), dan perguruan tinggi. Selanjutnya perhitungan yang dipakai menggunakan analisis persentase

Tabel 4. Jumlah dan persentase pedagang kaki lima berdasarkan kelompok tingkat pendidikan

\begin{tabular}{cccc}
\hline No. & $\begin{array}{c}\text { Pendidikan } \\
\text { (Tahun sukses) }\end{array}$ & Jumlah (orang) & Persentase (\%) \\
\hline 1. & Tamat SD & 13 & 29.5 \\
2. & Tamat SMP & 11 & 25.0 \\
3. & Tamat SMA & 17 & 38.6 \\
4. & Pendikan Tinggi & 3 & 6.8 \\
\hline & Jumlah & 44 & 100 \\
\hline
\end{tabular}

Sumber : Data diolah, 2019

Tabel 4 menunjukkan data tentang tingkat pendidikan kaki lima yang menjadi responden. Jumlah tingkat pendidikan yang berhasil ditempuh terbesar adalah SMA/Sederajat dengan persentase 70.5 persen, SMP dengan Persentase 25.0 persen, dan yang terkecil adalah perguruan tinggi dengan persentase 6.8 persen.

\section{Karakteristik menurut kelompok lamanya jam kerja}

Lamanya jam kerja dimaksud adalah waktu yang di perlukan untuk berdagang setiap hari. Pendistribusian jam kerja akan mempermudah analisa data. Sebelum mengetahui karakteristik responden berdasarkan jam kerja, terlebih dahulu dilakukan perhitungan skala interval jam kerja dengan kerja reponden tercepat yaitu 2 jam dan jam kerja terlama responden yaitu 13 jam. Range dari 2 jam ke 13 jam adalah 15 jam. Jika di penelitian ini mengunakan kali interval, maka jarak setiap interval adalah 15:6 $=2,5$ Artinya jarak interval kategori jam kerja responden 2 jam. Berikut adalah data kelompok lamanya jam kerja pedagang kaki lima yang menjadi responden adalah

Tabel 5. Jumlah dan persentase pedagang kaki lima berdasarkan kelompok lamanya jam kerja

\begin{tabular}{|c|c|c|c|}
\hline No. & Lamanya jam kerja (Jam) & Jumlah (Orang) & Persentase (\%) \\
\hline 1. & $2-3$ & 1 & 11.04 \\
\hline 2. & $6-7$ & 17 & 20.5 \\
\hline 3. & $8-9$ & 10 & 31.08 \\
\hline 4. & $10-11$ & 9 & 6.8 \\
\hline 5. & $12-13$ & 2 & 4.5 \\
\hline & Jumlah & 44 & 100 \\
\hline & Rata-Rata & \multicolumn{2}{|c|}{8 Jam } \\
\hline
\end{tabular}

Sumber : Data diolah, 2019

Tabel 5 menunjukan data bahwa lamanya jam kerja pedagang kaki lima yang menjadi responden terbesar adalah lamanya jam kerja 8-9 jam dengan persentase 38,06 persen. Lalu disusul lamanya jam kerja 10-11 jam dengan persentase 22.7 persen, 
dususul dengan urutan ke tiga lamanya jam kerja 12-13 jam yaitu dengan persentase 20.05 persen, dan disusul lagi dengan urutan keempat lamanya jam kerja 6-7 jam dengan persentase 15.9 disusul dengan kelima 12-13 jam kerja dengan persentase 20.5 persen. Sedangkan yang jumlah jam kerja yang paling terkecil adalah jumlah jam kerja 2-3 jam dengan persentase 2.3 persen.Untuk rata-rata (Mean) dari responden menurut lamanya jam kerja adalah 8 jam. Secara rata-rata, jumlah jam kerja pedagang kaki lima yang berada di kawasan Jembantan Gentala Arasy merupakan jam normal atau penuh karena jam kerjanya> 21 jam dalam seminggu.

\section{Karakteristik menurut kelompok status pekerjaan}

Yang dimaksud dengan status pekerjaan adalah apakah pedagang kaki lima yang menjadi pedagang kaki lima tersebut.

Tabel 6. Jumlah dan persentase pedagang kaki limaberdasarkan kelompok status pekerjaan

\begin{tabular}{cccc}
\hline No & Status pekerjaan & Frekuensi & Persentase (\%) \\
\hline 1 & Utama & 26 & 59.1 \\
2 & Sampingan & 18 & 40.9 \\
\hline & Jumlah & $\mathbf{4 4}$ & $\mathbf{1 0 0}$ \\
\hline
\end{tabular}

Sumber : Data diolah, 2019

Hampir semua pedagang kaki lima yang menjadi responden status pekerjaannya utama yaitu dengan persentase sebesar 59.1 persendan sisanya dengan persentase 40.9 persenatau 18 orang menjadikan pedagang kaki lima sebagai pekerjaan sampingan, mereka mempunya ipekerja utama sebagai security dan petani dan lainya.

\section{Karakteristik menurut kelompok modal}

Jumlah modal yang dimaksud dalam penelitian ini ada dua yaitu modal tetap dan modal operasional. Yang dimaksud dalam modal tetap disini adalah seperti gerobak, payung,mesin dan lainnya yang dibeli pada saat awal membuka usaha. Sedangkan modal biaya operasional adalah modal yang dikeluarkan pedagang untuk bahan-bahan baku dengan dalam satu hari.

\section{Karakteristik menurut kelompok modal tetap}

Modal tetap adalah modal yang harus pada awal memulai usaha, dan biasanya dipakai untuk jangka panjang. Contohnya pada pedagang kaki lima adalah kendaraan bermotor, gerobak, payung, mesin es tebu, etalase, kursimeja, gelas, piring dan lainya. Biasanya modal usaha ini nilainya cukup besar karena untuk jangka panjang.

Sebelum mengetahui karakteristik responden berdasarkan modal tetap, terlebih dahulu dilakukan perhitungan skala interval dengan modal tetap responden dari yang terkecil yaitu Rp.200.000 sampai 6.000.000. Range dari Rp. 200.000 ke Rp. 6.000.000 adalah Rp.5.800.000. Jika di penelitian ini menggunakan 4 kali intervel maka jarak setiap interval adalah Rp.5.800.000 :4= Rp.1.450.000. Artinya jarak kategori modal tetap responden adalah Rp.1.450.000.

Tabel 7. Jumlah dan persentase pedagang kaki lima berdasarkan kelompok modal tetap

\begin{tabular}{cccc}
\hline No. & Jumlah Modal Tetap (Rupiah) & Jumlah (Orang) & Persentase(\%) \\
\hline 1. & $200.000-2.500 .000$ & 28 & 61.4 \\
2. & $2.501 .000-3.500 .000$ & 13 & 25.0 \\
3. & $3.501 .000-4.500 .000$ & 2 & 9.1 \\
4. & $4.501 .000-6.000 .000$ & 1 & 2.3 \\
\hline \multicolumn{4}{c}{ Jumlah } \\
Rata-Rata & $\mathbf{4 4}$ Rp.2.000.000 \\
\hline
\end{tabular}

Sumber : Data diolah, 2019 
Dari tabel 7 dapat diketahui bahwa responden terbanyak adalah dengan modal tetap Rp.200.000 - 2.500 .000 dengan persentase sebesar $63.6 \%$ persen. Hal ini dikarenakan pada sektor informal mempunyai ciri-ciri modal yang kecil. Dan jumlah yang terkecil adalah modal tetap Rp.4.501.000-Rp.5.000.000 Rp.5.501.000Rp.6.000.000 dengan persentase yang samayaitu $2.3 \%$ persen. Untuk rata-rata responden menurut modal tetapa dalah Rp.2.000.000.

\section{Karakteristik menurut kelompok modal biaya perasional}

Biaya operasional adalah modal yang harus di keluarkan untuk membeli atau membuat barang dagangan. Biaya operasional ini bisa di keluarkan setiap hari. Untuk pedagang kaki lima, khususnya yang berjualan makanan dan minuman atau minuman biaya operasional biasanya dikeluarkan setiap hari untuk bahan membuat makanan dan minuman tersebut.

Sebelum mengetahui Karakteristik responden berdasarkan biaya operasional ,terlebih dahulu dilakukan perhitungan skala interval dengan modal operasional responden dari yang terkecil yaitu Rp.200.000 sampai Rp.3.100.000. range dari Rp.200.000 sampaiRp.3.100.000 adalah Rp.2.900.000. Jika di penelitian ini mengunakan 5 kali interval, maka jarak setiap interval adalah Rp.2.900.000 : $5=$ Rp.580.000. Artinya jarak interval kategori modal tetap responden adalah Rp.580.

Tabel 8. Jumlah dan persentase pedagang kaki lima berdasarkan kelompok modal biaya operasional (perbulan)

\begin{tabular}{clcc}
\hline No & $\begin{array}{c}\text { Iumlah Modal BiayaOperasional } \\
\text { (Rupiah) }\end{array}$ & $\begin{array}{c}\text { Jumlah } \\
\text { (Orang) }\end{array}$ & $\begin{array}{c}\text { Persentase } \\
(\boldsymbol{\%})\end{array}$ \\
\hline 1 & p.200.000 - Rp.780.000 & 30 & 68.2 \\
2 & Rp.781.000 - Rp.1.360.000 & 7 & 15.9 \\
3 & Rp.1.361.000 - Rp. 1.940 .000 & 1 & 2.3 \\
4 & Rp.1.941.000 - Rp. 2.520 .000 & 3 & 6.8 \\
5 & Rp2.521.000 - Rp.3.100.000 & 3 & 6.8 \\
\hline & Jumlah & $\mathbf{4 4}$ & $\mathbf{1 0 0}$ \\
\hline \multicolumn{2}{c}{ Rata-Rata } & Rp.375.000.00
\end{tabular}

Sumber: Data diolah, 2019

Tabel 8, dapat dilihat bahwa biaya operasional terbanyak terletak pada Rp.200.000 - Rp.780.000 dengan persentase sebesar 68.2 persen. Biaya operasional terkecil terletak pada Rp.1.361.000 - Rp.1.940.000 dengan persentase 2.3 persen.untuk Untuk biaya operasional yang terbanyak terletak pada Rp.200.000 - Rp.780.000 pada tabel. Untuk rata-rata (mean) biaya operasional adalah Rp.375.000.00. Hal ini dikarenakan ciri-ciri dari sektor informal tidak mermulakan modal yang cukup besar dalam Operasionalnya.

\section{Karakteristik menurut kelompok pendapatan bersih}

Pendapatan merupakan salah satu indikator ekonomi yang paling menentukan baik atau tidaknya keadaan Sosial Ekonomi seseorang. Smakin tinggi pendapatan yang diterima maka semakin meningkat pula kesejahteraan yang dicapainya. Pendapatan kotor dari pedagang kaki lima yang menjadi responden. Pendapatan bersih adalah dari pedagang kaki lima yang manjadi responden .pendapatan bersih adalah selisih positif dari total pendapatan operasional,dan non operasional ,dengan total biaya operasional dan biaya operasional dengan akumulasi satu bulan setelah dikurangin dengan taksiran pendapatan. 
Sebelum mengetahui karakteristik responden berdasarkan pendapatan bersih terlebih dahulu dilakukan perhitungan skala interval penndapatan dengan pendapatan responden dari yang terkecil yaitu Rp.3.300.000 sampai Rp.4.550.000. adalah Rp.4.220.000. jika di penelitian ini mengunakan 5 kali interval, maka jarak setiap interval adalah Rp.4.220.000 : $5=$ Rp.8440.000. Artinya jarak interval kategori pendapatan kotor responden adalah Rp.8440.000.

Tabel 9. Jumlah dan persensentase pedagang kaki lima berdasarkan kelompok pendapatan bersih (perbulan)

\begin{tabular}{|c|c|c|c|}
\hline No. & $\begin{array}{l}\text { Pendapatan Bersih } \\
\text { (Perbulan) }\end{array}$ & Jumlah (orang) & $\begin{array}{c}\text { Persentase } \\
(\%)\end{array}$ \\
\hline 1. & Rp.1.000.000 - Rp.2.000.000 & 23 & 52.3 \\
\hline 2. & Rp.2.001.000 - Rp.3.000.000 & 7 & 15.9 \\
\hline 3. & Rp.3.001.000 - Rp.4.000.000 & 6 & 13.6 \\
\hline 4. & Rp.4.001.000 - Rp.5.000.000 & 3 & 6.8 \\
\hline 5. & Rp.5.001.000 - Rp.6.000.000 & 5 & 11.4 \\
\hline & Jumlah & 44 & 100 \\
\hline & Rata-Rata & \multicolumn{2}{|c|}{ Rp.1.500.000 } \\
\hline
\end{tabular}

Sumber : Data diolah, 2019

Dari tabel 9 diketahui bahwa pendapatan bersih pedagang kaki lima yang menjadi responden yang terbanyak adalah pada pendapatan Rp.330.000 - Rp.1.174.000 dengan persentase 68.2 persen .lalu diikuti oleh pendapatan Rp.3.707.000 - Rp.4.550.00 dengan persentase 6.8 persen. untuk rata-rata dari responden menurut pendapatan bersih adalah Rp.1.500.000 perbulan.

Faktor yang mempengaruhi pendapatan pedagang kaki lima yang beradadi jembatan Gentala Arasy

\section{Interpretasi hasil regresi linier berganda}

Berdasarkan analisis dengan program SPSS20 for windows diperoleh hasil regresi berganda seperti terangkum pada tabel berikut:

Tabel 10. Hasil output regresi

\begin{tabular}{lcccc}
\hline No. & Variabel & Nilai koefisien & t hitung & Probabilita \\
\hline 1. & (Constant) & -0.925 & -0.985 & 0.331 \\
2. & Umur & 0.316 & 1.748 & 0.088 \\
3. & Tingkat pendidikan & -0.113 & -0.587 & 0.561 \\
4. & Jam Kerja & 0.322 & 1.921 & 0.062 \\
5. & Modal & -0.496 & 2.070 & 0.045 \\
\hline
\end{tabular}

Sumber: Data diolah, 2019

Berdasarkan tabel diatas diperoleh persamaan regresi berganda sebagaiberikut:

$$
\mathrm{PP}=0.985-1.748 \mathrm{UM}-\mathbf{0 . 0 5 8 7} \mathrm{TP}+1.921 \mathrm{JK}+2.070 \mathrm{MD}+\mathrm{e}
$$

Persamaan regresi tersebut mempunyai makna sebagai berikut :

Konstata nilai koefisien nya sebesar -0.985 ,artinya jika variabel umur,tingkat pendidikan,jam kerja dan modal tidak mengalami perubahan atau tetap, maka pendapatan PKL sebesar 0.985

Nilai koefisien modal adalah 1.748 ,hal ini menunjukan adanya hubungan positif, jika variabel umur mengalami kenaikan sebesar satu tahun, semantara tingkat pendidikan,jam kerja,modal dianggap tetap, maka akan menyebabkan menurunkan pendapatan PKL sebesar 1.748 . 
Nilai koefisien tingkat pendidikan adalah -0.587 , hal ini menunjukan adanya hubungan negatif jika variabel tingkat pendidikan mengalami kenaikan sebesar satu tahun semantara umur,jam kerja, dan modal diangap tetap maka akan menyebabkan penurunan pendapatan PKL sebesar -0.587

Nilai koefisien jam kerja adalah 1.921, hal ini menunjukan adanya hubungan positif, jika variabel umur, tingkat pendidikan dan modal dianggap tetap,maka akan menyebabkan kenaikan pendapatan PKL sebesar 1.921.

Nilai koefisien modal adalah 2.070 , hal ini menunjukan hubungan negatif jika variabel modal mengalami kenaikan sebesar Rp.1.000, semantara umur,tingkat pendidikan dan jam kerja dianggap tetap, maka akan menyebabkan peningkatan pendapatan PKL sebesar 2.070.

\section{Pengujian hipotesis}

Uji F

Uji F dilakukan untuk melihat kebartian pengaruh variabel independen secara simultan terhadap variabel dependen tau sering disebut uji kelinieran persamaan regresi. Untuk melakukan uji F dapatdilihat tabel anova dibawah ini :

Tabel 11.Hasil uji f statistik

\begin{tabular}{lcccccc}
\hline \multicolumn{7}{c}{ Anova $^{\mathbf{b}}$} \\
Model & Sum of squares & df & Mean square & F & Sig. \\
\hline 1 & Regresion & 19.210 & 4 & 4.802 & 3.348 & $0.019^{\mathrm{a}}$ \\
& Residual & 55.949 & 39 & 1.434 & & \\
& Total & 75.159 & 43 & & & \\
\multicolumn{7}{l}{ a.Predictors (constant),Modal,Pendidikan,Umur,JamKerja } \\
b.DependentVariabel : PendapatanBersih
\end{tabular}

\section{Sumber: Data diolah, 2019}

Pada tabel Anova diperoleh niali sig $=0.019^{\mathrm{a}}>0.05$ ini berarti variabel independen modal,pendidikan,umur, jam kerja dan modal secara simultan tidak berpengaruh signifikan terhadap variabel dependen pendapatan PKL. Maka dengan kata lain variabel pendidikan mampu menjelaskan besarnya variabel dependen pendapatan PKL.

\section{Uji t}

Uji t dilakukan untuk mengetahui apakah secara individu (persial) variabel independen mempengaruhivariabel dependen secara signifikannya dibawah 5\% maka secara persial modal,pendidikan, umur, dan jam kerja berpengaruh terhadap pendapatan PKL. Berikut ini dapat dijelaskan penguji hipotesis masing-masing variabel yaitu sebagai berikut:

\section{Varibel umur}

Dari hasil penngujian diperoleh umur sebesar 1.748. Dengan tingkat keyakinan $(\alpha$ $=1: 2=0.05) \mathrm{df}=(39)$ untuk pengujian diperoleh nilai $\mathrm{t}$ tabel1.685dari perhitungan

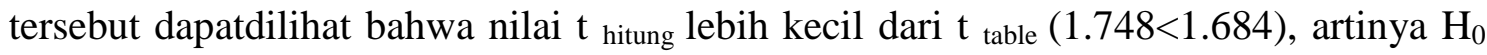
diterima dan $\mathrm{Ha}$ di tolak artinya umur berpengaruh signifikan terhadap pendapatan pedagang PKL. Dengan demikian hipotesis yang menyatakan pengaruh umur terhadap pendapatan pedagang PKL di Jembatan Gentala Arasy tahun 2019 benar dan terbukti. 


\section{Tingkat pendidikan}

Dari hasil pengujian diperoleh nilai $\mathrm{t}$ hitunguntuk variabel tingkat pendidikan sebesar -0.587 dengan tingkat keyakinan $(\alpha=5 \%)$ df $=(39)$ untuk pengujian di peroleh nilai $t$ tabel 1.684 dari perhitungan tersebut dapat dilihat bahwa nilai $t$ hitunglebih kecil dari $\mathrm{t}$ tabel $(-0.587<1.685)$, artinya Ho diterima dan Ha di tolak artinya Tingkat Pendidikan tidak berpengaruh signifikan terhadap pendapatan pedagang PKL. Dengan demikian hipotesis yang menyatakan pengaruh Tingkat pendidikan terhadap pendapatan pedagang PKL di Jembatan Gentala Arasy tahun 2019 tidak benar dan tidak terbukti

\section{Jam kerja}

Dari hasilpengujiandiperolehnilai t hitunguntukvariabel jam kerja sebesar 1.921. dengan tingkat keyakinan $(\alpha=5 \%) \mathrm{df}=(39)$ untuk pengujian diperoleh nilai $\mathrm{t}$ tabel 1.684

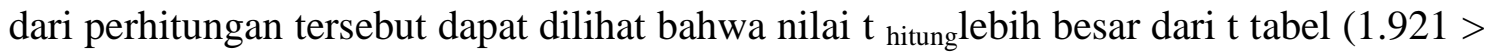
1.684) , artinya Ho ditolak dan Ha diterima artinya jam kerja berpengaruh signifikan terhadap pendapatan. Dengan demikian hipotesis yang menyatakan pengaruh jam kerja terhadap pendapatan PKL di Jembatan Gentala Arasy tahun 2019 benar dan terbukti.

\section{Modal}

Dari hasil pengujian diperoleh nilai $\mathrm{t}$ hitung untuk variabel modal sebesar 2.070. dengan tingkat keyakinan $(\alpha=5 \%) \mathrm{df}=(39)$ untuk pengujian diperoleh nilai $\mathrm{t}_{\text {hitung }}$ lebih kecil dari $t_{\text {tabel }}(2.070<1.684)$, artinya Ho ditolak dan Ha diterima Ha ditolak artinya modal berpengaruh signifikan terhadap pendapatan. Dengan demikian hipotesis yang menyatakan pengaruh umur terhadap pendapatan pedagang PKL di Jembatan Gentala Arasy tahun 2019 benar dan terbukti.

\section{Koefisien determinasi $\left(\mathbf{R}^{2}\right)$}

Analisis Koefisien determinasi (KD) digunakan untuk melihat beberapa besar variabel bebas berpengaruh terhadap variabel terikat yang dinyatakan dalam persentase seperti yang di tunjukan pada tabel berikut :

Tabel 12. Hasil uji $r^{2}$ square

\begin{tabular}{ccccc}
\hline Model & R & R Square & Adjusted R Square & Std. Error of the Estimate \\
\hline 1. & $0.506^{\alpha}$ & 0.256 & 0.179 & 1.19775 \\
\hline Sumber: Data diolah, 2019 & &
\end{tabular}

Tabel 12 diatas dapat kita lihat Model Summary diketahui nilai $\mathrm{R}_{\text {square }}$ sebesar 0.506. Artinya sebesar 0.506 persen variasi pendapatan PKL dijelaskan oleh variabel bebas dalam model, sedangkan sisahnya 97,44 persen di jelaskan oleh variabel lain diluar penelitian.

\section{Penguji asumsi klasik \\ Normalitas data}

Uji normalitas dapat dilihat pada grafik Normal P-plot sebagai berikut. 


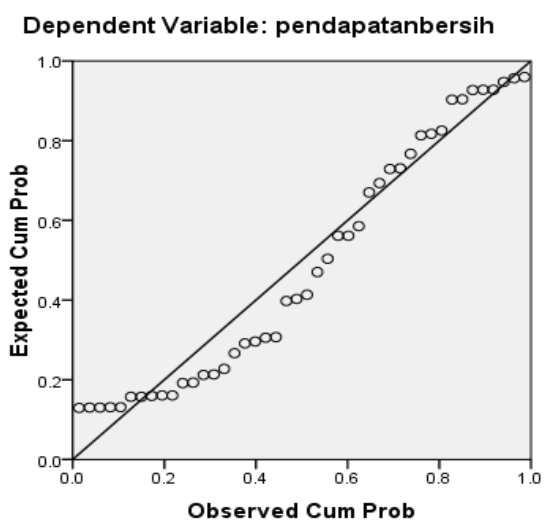

Gambar 1. Normalitas Data

Pada grafik P-plot terlihat data menyebar di sekitargaris diagonal dan mengikuti arah garis histograf menuju pola distribusi normal maka variabel dependen Y memenuhi asumsi klasik.

\section{Uji multikolonieritas}

Uji multikolonieritas bertujuan untuk mengujiapakah dalam model regresi ditemukan adanya kolerasi antar variabel bebas. Model regresi yang tinggi tidak terjadi korelasi antar variabel bebas. Untuk mendeteksi ada tidaknya multikolonieritas di dalam model regresi adalah dengan melihat nilai toleransi dan Variance Inflation faktor (VIF). Apabila nilai toleransi $>10 \%$ dan nilaiVIF $<10$ maka dapat disimpul kan tidak ada multikolonieritas antar Varibel bebasdalam model regresi. Berdasarkan tabel diatas telihat setiap variabel bebas mempunyai nilai $>0,1$ dan nilaiVIF $<10$. Jadi dapat disimpulkan bahwa tidak ada multikolonieritas antar Variabel bebas dalam model regresi ini.

Tabel 13. Hasil Uji multikolonieritas

\begin{tabular}{cllll}
\hline No & Variabel & \multicolumn{2}{c}{ Tollerance } & VIF \\
\hline 1 & UM & 0.953 & 1.016 & \\
2 & TP & 0.983 & 1.018 \\
3 & JK & 0.935 & 1.070 & \\
4 & MD & 0.925 & 1.081
\end{tabular}

Sumber: Data diolah, 2019

\section{Uji autokorelasi}

Autokorelasi didefinisikan sebagai korelasi/keterkaitan antara serangkaian observasi yang diurutkan menurut waktu dan ruang. Untuk mengetahui ada atau tidaknya gejala autokorelasi dalam perhitungan regresi atas penelitian ini maka digunakan Durbin-Watson Tessebesar 1.519. Dengan menggunakan tabel statistik dan derajat kepercayaan 95\% $(\alpha=0.05)$ jumlah observasi 44 serta jumlah varabel bebas 4 maka di peroleh angka dl $=1.3263$ dan du $=1.7200$ sedangkan nilai untuk 4-dl $=$ 2.6737dan 4-du $=2.28$ dengan mengunakan uji statistik Durbin Watson maka patokan yang digunkan adalah sebagai berikut :

$\mathrm{d}<\mathrm{dl}=$ berati terdapat autokorelasi

$\mathrm{d}>\mathrm{dl}=$ berati tidak terdapat autokorelasi positif

(4-d) $<\mathrm{dl}=$ berati terdapat autokorelasi negatif

$(4-d)>d l=$ berati tidak terdapat autokerelasi negatif 
$\mathrm{du}<\mathrm{d}<(4-\mathrm{du})=$ berati tidak terdapat autokorelasi

$\mathrm{dl}<\mathrm{d}<\mathrm{du}$ atau $(4-\mathrm{du})=$ berati tidak dapat disimpulkan

Hasil yang diperoleh adalah nilai DW observasi terletak pada daerah (4-d) $<$ du atau terdapat autokorelasi negatif.

\section{Uji Heteroskeditas}

Mendeteksi heteroskedastisitas dapat dilakukan dengangan bergrafik nilai-nilai residu, uji Breusch-Godfrey dan Uju park. Penelitian ini mengunakan uji BreuschGodfrey.

\section{Scatterplot}

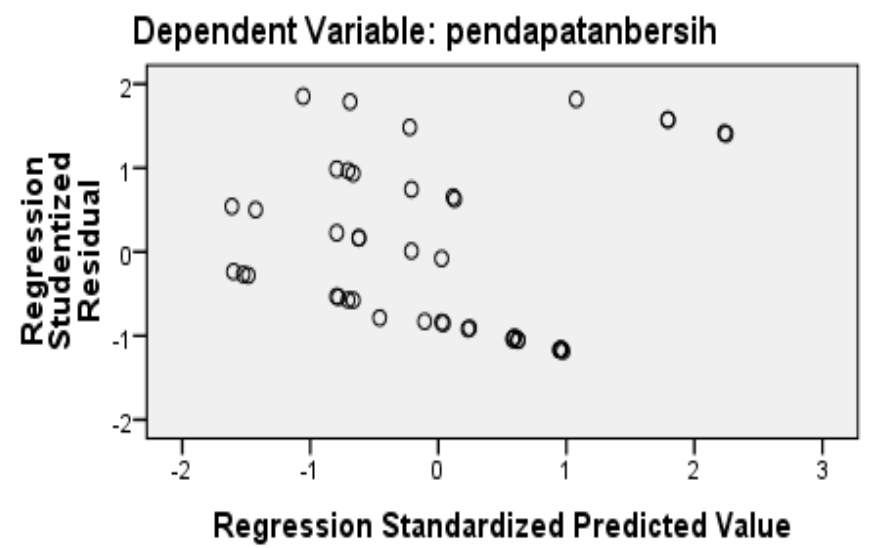

Gambar 2. Uji Heteroskedastisitas

Pada gambar scatterplot terlihat bahwa titik-titik menyebar secara acak serta tersebar tinggi di atas sumbu $\mathrm{Y}$. Hal ini dapat disimpulkan tidak terjadi heteroskedastisitas pada model regresi ini.

\section{HASIL PENELITIAN}

Berdasarkan Hasil analisis penelitian tentang kondisi sosial ekonomi pekerja sektor informal.variabel bebas umur,tingkat pendidikan,jam kerja secara bersama-sama ada yang mempengaruhi variabel dependen pendapatan PKL sebesar 2.56 persen dan sisahnya dipengaruhi oleh variabel lain yaitu sebesar 97.44persen.

\section{Pengaruh umur terhadap pendapatan PKL}

Hasil regresi dengan menggunakan analisis regresi tersebut menunjukan bahwa nilai koefisisen variable umura dalah 0.316 , artinya jika rata-rata usia pedagang makanan dan minuman lebih muda satu tahun dibandingkan umur sekarang maka pendapatan akan meningkat.

Pengujian diperoleh nilai $\mathrm{t}$ tabel 1.748 dari perhitungan tersebut dapat dilihat

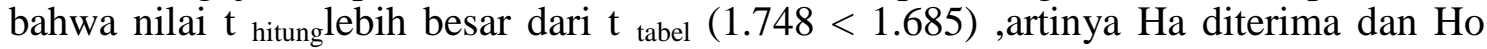
ditolak artinya umur berpengaruh signifikan terhadap PKL.Hal ini sependapat dengan teori yang di kemukakan oleh (Cahyono, 1998) umur produktif berkisar antara 15-64 tahun yang merupakan umur ideal bagi para pekerja. Dimasa produktif, secara umum semakin bertambahnya umur maka pendapatan akan semakin meningkat, yang tergantung juga pada jenis pekerjaan yang di lakukan. Kekuatan fisik seseorang untuk melakukan aktivitas sangat erat kaitannya dengan umur karena bila umur seseorang untuk melakukan akifitas sangat erat kaitannya dengan umur karena bila umur seseorang telah melewati masa produktivitasnya pun menurun dan pendapatan juga ikut turun. 


\section{Pengaruh tingkat pendidikan terhadap pendapatan PKL}

Hasil regresi dengan menggunakan analisis regresi berganda tersebut menunjukan bahwa nilai koefisien variabel tingkat pendidikan adalah -0.113 artinya jika variabel tingkat pendidikan mengalami kenaikan sebesar satu tahun, semantara modal, umur, dan jam kerja dianggap tetap maka akan menyebabkan peningkatan pendapatan PKL.

Pengujian diperoleh nilai $\mathrm{t}$ tabel $(0.587<1,685)$, artinya Ho diterima dan $\mathrm{Ha}$ ditolak artinya tingkat pendidikan tidak berpengaruh signifikan terhadap pendapatan. Hal ini tidak sepen dapat dengan Arianto dalam Nurhayati (2017) yang mengatakan tingkat pendidikan yang dimiliki memberikan pengetahuan bukan hanya dalam pelaksanaan kerja, tetapi juga landasan untuk mengembangkan diri dalam memanfatkan sarana dan prasarana demi kelancaran pekerjaan.

\section{Pengaruh lama jam kerja terhadap pendapatan PKL}

Hasil regresi dengan menggunakan analisis regresi berganda tersebut menunjukan bahwa nilai koefisien variabel jam kerja adalah 0.322 artinya jika variabel jam kerja mengalami kenaikan sebesar satu jam, semantara modal, umur dan tingkat pendidikan dianggap tetap, maka akan menyebabkan peningkatan pendapatan PKL.

Pengujian diperoleh nilai $\mathrm{t}$ tabel perhitungan tersebut dapat dilihat bahwa nilai $\mathrm{t}$ hitunglebih besar dari $t$ tabel $(1.921>1.685)$, artinya Ho ditolak dan Ha diterima artinya jam kerja berpengaruh signifikan terhadap pendapatan. Hal ini sependapat dengan hasil penelitian Jafar dalam Akhbar nurserta (2015) membuktikan adanya hubungan langsung antara jam kerja dengan tingkat pendapatan, setiap penambahan waktu operasi akan makin membuka peluang bagi bertambahnya omzet penjualan.

\section{Pengaruh modal terhadap pendapatan PKL}

Hasil regresi dengan menggunakan analisis regresi berganda tersebut menunjukan bahwa nilai koefisien 0.496 artinya jika rata-rata usia pedagang makanan dan minuman lebih muda satu tahun dibandingkan umur sekarang maka pendapatan akan menurun.

Pengujian diperoleh nilai t hitung lebih kecil dari t tabel 2.070 dari perhitungan tersebut dapat dilihat bahwa nilai t hitung lebih besar dari t tabel $(2.070<1.685)$, artinya Ho diterima dan Ha ditolak artinya tingkat pendidikan berpengaruh siginifikan terhadap pendapatan. Hal ini sependapat oleh Suparmoko dalam Akhbar nuserta (2015) menyatakan modal merupakan input (faktor produksi) yang sangat penting dalam menentukan tinggi rendahnya pendapatan. Tetapi bukan berarti merupakan faktor satusatunya yang dapat meningkatkan pendapatan.

\section{KESIMPULAN DAN SARAN Kesimpulan}

Berdasarkan hasil dan pembahasan sebelumnya dapat ditarik beberapa kesimpulan yaitu, karakteristik pedagang kaki lima yang menjadi responden menurut umur rata-rata 25 tahun, jenis kelaamin yang terbanyak laki-laki dengan persentase 63.6 persen. Menurut jumlah tanggungan keluarga rata-rata pedagang kaki lima yang menjadi responden memiliki 3 tanggungan. Menurut tingkat pendidikan jumlah terbanyak SMA dengan persentase 38.6 persen, dari lamanya jam kerja rata-rata pedagang kaki lima yang menjadi responden mempunyai 8 jam waktu bekerja dalam sehari. Untuk status pekerjaan yang terbanyak yaitu pekerjaan utama dengan persentase 59.1. Untuk modal tetap, pedagang kaki lima yang menjadi responden memulai usaha dengan dengan rata-rata sebesar Rp.2.000.000 Modal biaya operasional dengan rata-rata Rp.375.000.00dan untuk pendapatan bersih, pedagang kaki lima yang menjadi responden memperoleh rata-rata Rp.1.500.000 perbulan. 
Hasil regresi menunjukan bahwa variabel Umur, Jam kerja dan Modal berpengruh signifikan terhadap pendapatan pedagang kaki lima, dan variabel tingkat pendidikan tidak berpengaruh signifikan terhadap pedagang kaki lima.

\section{Saran}

Bertitik tolak dari hasil penelitian diharapkan para pedagang kaki lima yang berada di lingkungan Jembatan Gentala Arasy Kota Jambi untuk menambah modal operasional dan mengoptimalkan jumlah jam kerja supaya bisa menaikkan jumlah pendapatan yang didapat. Hasil penelitian ini sekiranya dapat dijadikan acuan bagi pemerintah ataupun instansi yang berkaitan kepada pedagang kaki lima untuk lebih memperhatikan atau bahkan memberi fasilitas yang cukup untuk pedagang kaki lima. Dengan penataan yang tepat, pedagang kaki lima mungkin juga bisa menjadi alternatif untuk masalah pengagguran.

\section{DAFTAR PUSTAKA}

Breman,Jan. (2000). The informal sector in research: theory and practice. Rotterdam: The Comparative Asian Studies Programme (CASP), University of Rotterdam.

Fitria, N.A. (2014). Analisis Faktor-Faktor Yang Mempengaruhi Pendapatan Pedagang Tape Singkong Di Kota Probolinggo.http://jimfeb.ub.ac.id/index.php/jimfeb/arti cle/ view/1192. Diunduh 10 Januari 2019.

Hasan, M. Iqbal. (2002). Pokok-pokok Materi Metodologi Penelitian dan Aplikasinya. Ghalia Indonesia. Bogor

Marhaeni, A.A.I.N dan I.G.A., Manuati Dewi. (2004). Ekonomi Sumber Daya Manusia . Buku Ajar Fakultas Ekonomi Universitas Udayana. Denpasar.

Prawiro, Kusumo. (2001). Ekonomi Rakyat: Konsep, Kebijakan, dan Strategi. Yogyakarta: BPFE.

Sudarmini, Ni Nyoman. (2006). Peranan Pekerja Perempuan dalam Menunjang Pendapatan Keluarga Pada Industri Kecil dan Kerajinan Rumah Tangga di Kabupaten Gianyar. Denpasar: Universitas Udayana Diunduh 10 Januari 2019.

Sugeng Haryanto. (2009). Peran Aktif Wanita Dalam Meningkatkan Pendapatan Rumah Tangga Miskin. Model Ekonomi Rumah Tangga Miskin, Jakarta

Sugiyono. (2013). Metode Penelitian Pendidikan Pendekatan Kuantitatif, Kualitatif, dan $R \& D$. Bandung: Alfabeta

Winarno,W.W. (2011). Analisis Ekonometrika dan Statistika dengan EViews. Edisi Ketiga, Cetakan pertama. UPP STIM YKPN.Yogyakarta

Wohon, Selvina dkk. (2017). Penentuan Model Regresi Terbaik dengan Menggunakan Metode Stepwise (Studi Kasus:Impor Beras di Sulawesi Utara).Jurnal Ilmiah Sains. 17(2), 80-88. 